\title{
The Importance of Digital Trust in E-Commerce: Between Brand Image and Customer Loyalty
}

\author{
Daniel Hermawan
}

Business Administration Department, Parahyangan Catholic University, Bandung, Indonesia

\section{ARTICLE INFO}

Keywords:
Brand image
Customer loyalty
Digital trust
E-commerce
Technology

\begin{abstract}
Technology becomes an important part that cannot be separated from human life today, including the business world. The ease, speed, and practicality provided by technology indirectly changes people's lifestyles, both in social relations and product consumption behavior. Online shopping is one phenomenon that arises because of technological advancements. Simply access the internet with a device, customer can get the desired item without having to leave the house or need to go to the store. The shift in consumer spending patterns from traditional to digital also raises a new challenge, namely digital trust. If a conventional store guarantees service quality, it becomes a question of how e-commerce currently present in Indonesia is maintaining customer trust, especially when customer never meet seller face-to-face and only mediating using e-commerce platform. Through this research, the authors are interested in discussing (1) the importance of digital trust in e-commerce; (2) how digital trust affects the brand image of e-commerce; (3) how digital trust affects customer loyalty. This study uses a quantitative approach with methods of collecting data through questionnaires and observations e-commerce's customer in Bandung, Indonesia.
\end{abstract}

\section{Introduction}

Technology becomes an inseparable part of the life of modern society, from social activities, communication, transportation, to the business world. Easy, fast, and practical to be added value offered by technology that changes people's lifestyles, especially those in urban areas. One of the growing phenomena in Indonesia is online shopping.

Bank Indonesia mentions if online store transactions (e-commerce) in Indonesia in 2018 reached IDR 77.766 trillion and increased 151\% compared to 2017 which reached IDR 30.942 trillion (Daniel, 2019). This shows that the phenomenon of online shopping is increasingly in demand by consumers in Indonesia. Some reasons why consumers in Indonesia like online shopping are (1) saving time and energy, (2) there are many promos, (3) more payment options, (4) having more complete variants of goods, and (5) being able to compare prices (Wahyuningsih, 2018).

Although the phenomenon of online shopping is increasing, consumers must be aware of security when shopping online. The Indonesian Consumers Foundation (Yayasan Lembaga Konsumen Indonesia/YLKI) gets many complaints related to online shopping, which is $24 \%$ of consumer money lost in online shopping transactions (Hartomo, 2019). Other complaints, such as items received by consumers damaged, inappropriate, or late in shipping also become a problem that arises along with the increasing interest of the people to shop online.

Responding to security issue in online shopping transaction, e-commerce must also pay attention to public trust in cyberspace called digital trust. Similar to maintaining consumer trust

* Corresponding Author E-Mail Address: daniel.hermawan@unpar.ac.id 
in conventional stores, online stores must also be able to make consumers believe in the various features provided in e-commerce, ranging from online shop ratings, comments, the number of transactions that have been occur, and testimonials from other consumers who have already bought.

In digital trust, there are various actors who play a role in the ecosystem of online shopping transactions, namely buyers, sellers, and intermediaries in this case is the platform used in online shopping transactions (e-commerce). The quality of interaction between sellers and buyers is not only independent, but also influenced by e-commerce.

Places advertisement

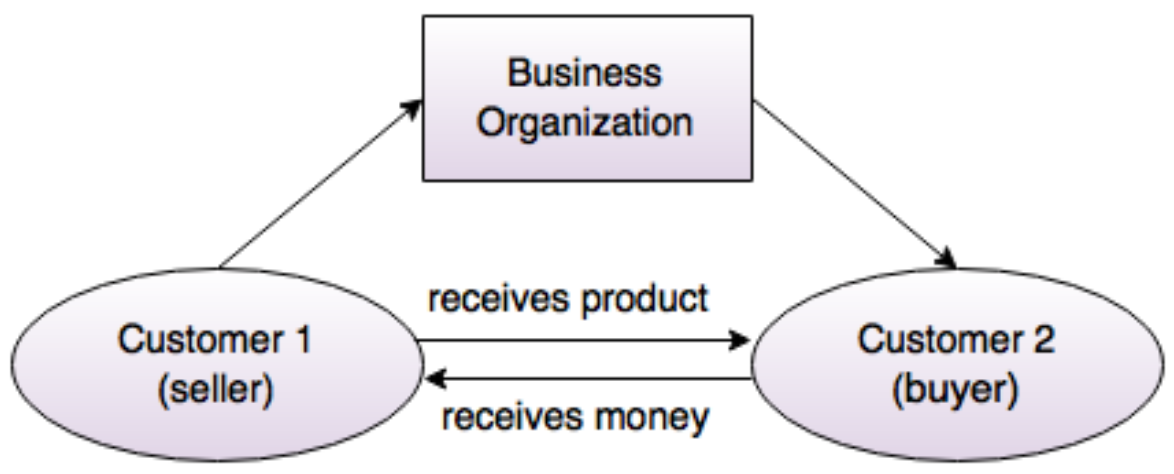

Figure 1: C2C e-Commerce Business Model (Source: (CareerRide.com, 2019)

In this model, $\mathrm{C} 2 \mathrm{C}$ (Consumer to Consumer) business model helps consumers to sell their assets like residential property, cars, motorcycles, etc., or rent a room by publishing their information on the website (Tutorials Point, 2019). Sellers can sell their products, goods or services directly to the consumer online. Consumers can view and compare products on the website that they want to buy and can order. After receiving the order details, the company will process the orders and then send products directly to the customer. For example, Shopee, Lazada, etc. are these types of C2C's e-commerce business models which we are using in our daily life. We can view products on e-commerce and can order it. After receiving the order, the seller processes and sends it to us. Here a business company is selling their products to the customer with the help of an e-commerce website (Das, 2018).

Also, there's B2C (Business to Consumer) business model that sells its products directly to a customer. A customer can view the products shown on the website. The customer can choose a product and order the same. The website will then send a notification to the business organization via e-mail and the organization will dispatch the product/goods to the customer (Tutorials Point, 2019). B2C e-commerce business model also adapted by several e-commerce, such as JD.id, Blibli, etc.

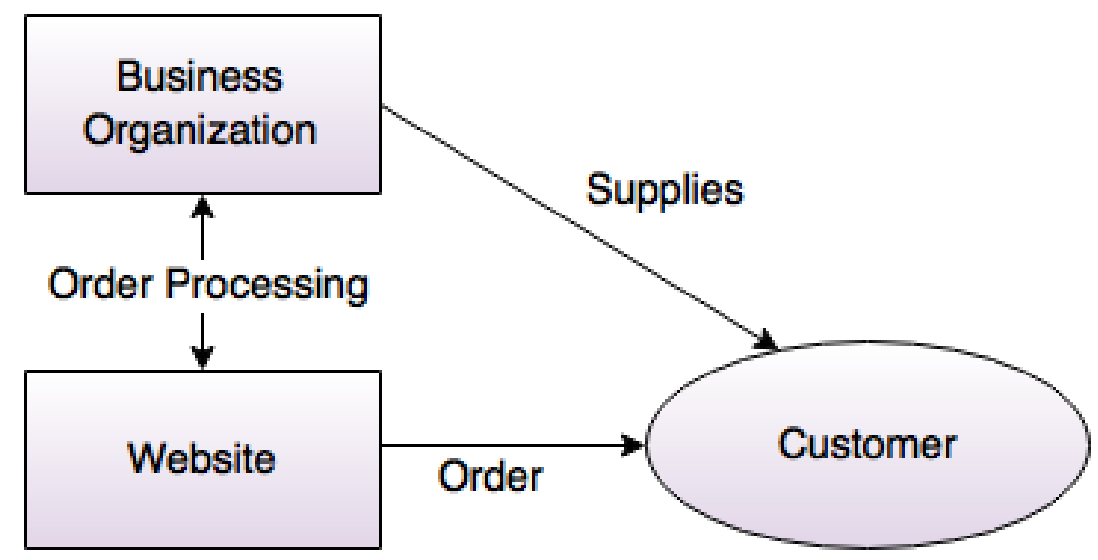

Figure 2: B2C e-Commerce Business Model. Source:(CareerRide.com, 2019) 
On a global scale, the level of digital trust in Indonesia is classified as low, measured from 4 dimensions, namely attitudes, behaviour, environment, and experience. Indonesia positioning in rank 37 and obtained a digital trust score in average 2.19, consists of four elements, that're attitude 2.91, behaviour 2.60, environment 2.27, and experience 0.98 (Chakravorti, Bhalla, \& Chaturvedi, 2018). It can be seen if the experience score of Indonesia globally is at the lowest level of trust in digital trust which correlates with the number of consumer complaints when do online shopping.

Table 1.

Digital Trust Index among 42 Countries

\begin{tabular}{cccccc}
\hline No & Country & $\begin{array}{c}\text { Average Digital Trust } \\
\text { Index }\end{array}$ & No & Country & $\begin{array}{c}\text { Average Digital } \\
\text { Trust Index }\end{array}$ \\
\hline 1 & Sweden & 3.155 & 22 & United States & 2.5625 \\
2 & Switzerland & 3.0925 & 23 & Canada & 2.535 \\
3 & Norway & 2.995 & 24 & Hungary & 2.5275 \\
4 & Singapore & 2.9825 & 25 & Peru & 2.5075 \\
5 & Finland & 2.97 & 26 & Turkey & 2.5025 \\
6 & Netherlands & 2.915 & 27 & Thailand & 2.4425 \\
7 & Hong Kong & 2.865 & 28 & France & 2.4225 \\
8 & Estonia & 2.855 & 29 & China & 2.415 \\
9 & Japan & 2.7675 & 30 & Malaysia & 2.39 \\
10 & Spain & 2.765 & 31 & Chile & 2.3275 \\
11 & South Korea & 2.7275 & 32 & Saudi Arabia & 2.29 \\
12 & Germany & 2.725 & 33 & Vietnam & 2.2825 \\
13 & United Kingdom & 2.72 & 34 & Philippines & 2.2575 \\
14 & Italy & 2.6925 & 35 & Colombia & 2.2075 \\
15 & Australia & 2.6825 & 36 & India & 2.1975 \\
16 & Ireland & 2.6825 & 37 & Indonesia & 2.19 \\
17 & Slovenia & 2.6475 & 38 & Mexico & 2.115 \\
18 & Poland & 2.62 & 39 & Brazil & 2.11 \\
19 & New Zealand & 2.605 & 40 & Jordan & 2.085 \\
20 & Bulgaria & 2.6 & 41 & Egypt & 1.97 \\
21 & Russia & 2.59 & 42 & Pakistan & 1.705 \\
\hline
\end{tabular}

Source: (Chakravorti, Bhalla, \& Chaturvedi, 2018)

Seeing the phenomenon of digital trust in online shopping transactions, as well as the low digital trust of Indonesians in their online shopping experience, the authors are interested in knowing (1) the importance of digital trust in e-commerce; (2) how digital trust affects the brand image of e-commerce; (3) how digital trusts affect customer loyalty mediated by brand image.

\section{Literature Review}

\subsection{Digital Trust}

Digital trust can be defined as a strong belief in a person's reliability, truth or ability or something (Oxford University Press, 2019). Consumer trust is another dimension that is able to improve relationship quality, thus positively affecting customer relationship commitment and customer loyalty (Hajli, Mohana Shanmugam, Savvas Papagiannidis, Debra Zahay, \& Marie-Odile Richard, 2017). Consumer trust refers to the credibility of consumers that a company will provide a product or service as expected. 
There are several indicators for measuring digital trust, namely (1) reliability, (2) credibility, (3) transparency, (4) integrity, and (5) security (KPMG, 2015).

Table 2

Digital Trust's Indicator

\begin{tabular}{cl}
\hline Indicator & \multicolumn{1}{c}{ Measurement } \\
\hline Reliability & $\begin{array}{l}\text { Digital services need to be reliable and available to meet consumer demands } \\
\text { Consumers will switch services where organisations do not fulfil their promises or } \\
\text { commitments }\end{array}$ \\
Transparency & $\begin{array}{l}\text { Consumers are demanding greater visibility over how their data is used } \\
\text { Integrity }\end{array}$ \\
Organisations need to demonstrate that they act in the best interests of consumers \\
& $\begin{array}{l}\text { Consumers will be unlikely to provide data or accept new services if they don't believe } \\
\text { your digital service is secure }\end{array}$ \\
\hline
\end{tabular}

Source: (KPMG, 2015)

\subsection{Brand Image}

Brand image is a picture and trust that is embedded in the minds of consumers towards associations that are remembered by consumers (Kotler \& Keller, 2013). The positive image of the brand will encourage consumers to make repeat purchases. Brand image is often referenced in the psychological aspects of the image that is built into the subconscious of consumers through the expectations and experience of taking the brand over a product or service, thus forming a positive brand of becoming increasingly important to be owned by the company (Pujadi, 2010). The brand image is also regarded as a description of the company which includes the symbolic meaning associated with the specific attributes of products or services (Winarso, 2012).

\subsection{Customer Loyalty}

Customer loyalty, which generally refers to the strong commitment to repurchase a preferred product or service (Kim, Myeong-Cheol Park, Jong-Hyun Park, Jimin Kim, \& Eunhye Kim, 2018). Two basic approaches to behavioral loyalty and attitudinal approaches. Behavioral loyalty is defined as multiple repetition of purchase. The attitude loyalty approach is recommending certain products for others to try (Kement \& Çavuşoğlu, 2017).

There are six reasons why customer loyalty is very important for e-commerce: (1) existing customers are more prospective and provide big profits for the company; (2) the cost of obtaining new customers is far greater than maintaining and retaining existing customers; (3) customers who already believe in e-commerce will also believe in other matters; (4) ecommerce operating costs will be more efficient if they have many loyal customers; (5) companies can reduce psychological and social costs because loyal customers have had many positive experiences with e-commerce; (6) loyal customers will always defend e-commerce, even try to attract and advise others to become customers (words of mouth) (Chambers, 2018).

\subsection{Previous Research}

Research on brand trust and brand image has been carried out by Mohammad Deheshti, Javad Adabi Firouzjah, Hossein Alimohammadi in "The Relationship between Brand Image and Brand Trust in Consumers Sporting Goods" in 2016 consisted of 279 male and female athletes in the city of Qom, who were buying foreign sports brands. As a result, the components of services, variety, quality, and atmosphere could be predicted by the buyers of foreign sports brands (Deheshti, Firouzjah, \& Alimohammadi, 2016).

Likewise, research on trust, brand image, and the repurchase of intention in online shopping was carried out by Hendra Riki Wijaya and Sri Rahayu Tri Astuti with the title "The Effect of Trust and Brand Image for Intention in Online Shopping Repurchase" in 2018 to 130 
respondents who had bought the Berrybenka product. The result, e-service quality, customer satisfaction has a positive influence on trust and brand image (Wijaya \& Astuti, 2018).

Research on brand experience, brand image, brand trust, and brand loyalty has also been carried out by I Putu Yoga Semadi and Maya Ariyanti with the title "The Influence of Brand Experience, Brand Image and Brand Trust on Brand Loyalty of ABC-CASH" in 2018 to 350 users as the respondents. The result, the causality relationship among variables affected by brand experience, brand image, brand trust, and brand loyalty (Semadi \& Ariyanti, 2018).

Table 3.

Previous Research

\begin{tabular}{|c|c|c|c|}
\hline Researchers & $\begin{array}{l}\text { Mohammad Deheshti, } \\
\text { Javad Adabi Firouzjah, } \\
\text { Hossein Alimohammadi } \\
\end{array}$ & $\begin{array}{l}\text { Hendra Riki Wijaya, Sri } \\
\text { Rahayu Tri Astuti }\end{array}$ & $\begin{array}{l}\text { I Putu Yoga Semadi, Maya } \\
\text { Ariyanti }\end{array}$ \\
\hline Title & $\begin{array}{l}\text { The Relationship between } \\
\text { Brand Image and Brand } \\
\text { Trust in Sporting Goods } \\
\text { Consumers }\end{array}$ & $\begin{array}{l}\text { The Effect of Trust and } \\
\text { Brand Image to } \\
\text { Repurchase Intention in } \\
\text { Online Shopping }\end{array}$ & $\begin{array}{l}\text { The Influence Of Brand } \\
\text { Experience, Brand Image, and } \\
\text { Brand Trust on Brand Loyalty } \\
\text { Of } A B C-C A S H\end{array}$ \\
\hline Year & 2016 & $\begin{array}{l}2018 \\
\text { Analyze effect of e-service } \\
\text { quality to customer }\end{array}$ & 2018 \\
\hline $\begin{array}{l}\text { Aim of } \\
\text { Research }\end{array}$ & $\begin{array}{l}\text { Examine the relationship } \\
\text { between foreign brand } \\
\text { image and brand trust } \\
\text { among buyers of foreign } \\
\text { sports brands. }\end{array}$ & $\begin{array}{l}\text { satisfaction, customer } \\
\text { satisfaction to trust and } \\
\text { brand image, trust and } \\
\text { brand image to repurchase } \\
\text { intention in online } \\
\text { shopping (Case at } \\
\text { Berrybenka online } \\
\text { customer in Indonesia). }\end{array}$ & $\begin{array}{l}\text { Examine the brand loyalty that } \\
\text { is affected by the parameters of } \\
\text { brand experience, brand image, } \\
\text { and brand trust. }\end{array}$ \\
\hline $\begin{array}{l}\text { Type of } \\
\text { Research } \\
\text { Collection }\end{array}$ & Quantitative & Quantitative & Quantitative \\
\hline $\begin{array}{l}\text { Data } \\
\text { Technique }\end{array}$ & Survey & Survey & Survey \\
\hline $\begin{array}{l}\text { Research } \\
\text { Results }\end{array}$ & $\begin{array}{l}\text { The components of } \\
\text { services, variety, quality, } \\
\text { and atmosphere could } \\
\text { predict the significance of } \\
\text { the brand trust among the } \\
\text { buyers of foreign sports } \\
\text { brands. }\end{array}$ & $\begin{array}{l}\text { E-service quality had a } \\
\text { positive influence on } \\
\text { customer satisfaction, } \\
\text { customer satisfaction had a } \\
\text { positive influence on trust } \\
\text { and brand image, trust and } \\
\text { brand image had a positive } \\
\text { influence on repurchase } \\
\text { intention. }\end{array}$ & $\begin{array}{l}\text { The causality relationship } \\
\text { among the variables affected } \\
\text { and effected by brand } \\
\text { experience, brand image, brand } \\
\text { trust, and brand loyalty. }\end{array}$ \\
\hline
\end{tabular}

Source: (Deheshti, Firouzjah, \& Alimohammadi, 2016); (Wijaya \& Astuti, 2018); (Semadi \& Ariyanti, 2018)

Considering the studies and analysis from previous research, the following hypotheses have been developed.

$\mathrm{H}_{1}$ : Digital trust has positive and significant influence on brand image.

$\mathrm{H}_{2}$ : Digital trust has positive and significant influence on customer loyalty.

$\mathrm{H}_{3}$ : Brand image has positive and significant influence on customer loyalty.

$\mathrm{H}_{4}$ : Brand image is able to significantly mediate the influence of digital trust on customer loyalty. 


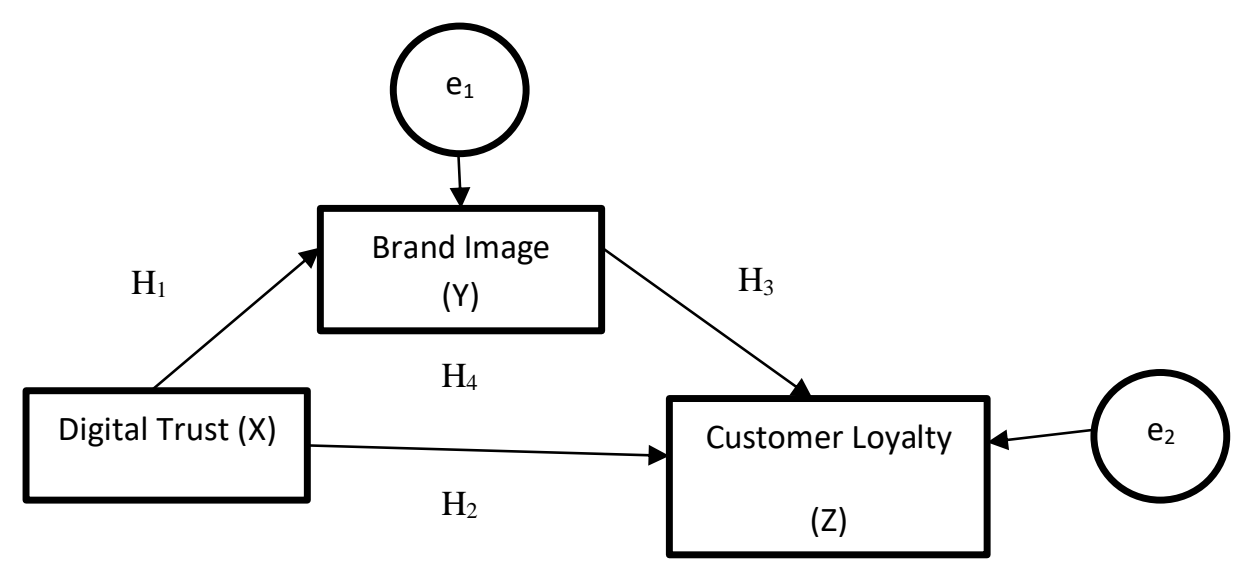

Figure 3: Conceptual Framework of Research

\section{Methods}

This study uses a quantitative method with a correlational approach. Quantitative methods are used to examine relationships between primary goals and to analyze and represent relationships that are mathematically through statistical analysis. Meanwhile, the correlational approach explores the relationships between variables using statistical analysis (Punch, 2013). Data obtained through questionnaires and processed with SPSS software. The variables to be analyzed in this study are digital trust, brand image, and customer loyalty. Research conducted in Bandung, Indonesia with 538 respondents.

Table 4.

e-Commerce's Profile in Indonesia

\begin{tabular}{|c|c|c|c|}
\hline No & e-Commerce & Profile & Source \\
\hline 1 & Shopee & $\begin{array}{l}\text { Shopee is an e-commerce platform headquartered in } \\
\text { Singapore under the SEA Group which was established in } \\
2009 \text { by Forrest Li with the Consumer to Consumer (C2C) } \\
\text { model. }\end{array}$ & (Cahya, 2018) \\
\hline 2 & JD.id & $\begin{array}{l}\text { JD Indonesia was formed in collaboration with JD.id, which } \\
\text { first operated in Indonesia in November 2015. JD.id is one of } \\
\text { the largest online B2C stores in China, Alibaba's biggest rival. }\end{array}$ & (Cahya, 2018) \\
\hline 3 & Bukalapak & $\begin{array}{l}\text { Bukalapak is an Indonesian marketplace established by } \\
\text { Achmad Zaky in early 2010. Bukalapak's business model } \\
\text { carries the concept of Consumer to Consumer (C2C). }\end{array}$ & (Cahya, 2018) \\
\hline 4 & Lazada Indonesia & $\begin{array}{l}\text { Lazada Indonesia is a branch of Lazada Group's online retail } \\
\text { network since } 2012 \text { which received funding from Rocket } \\
\text { Internet, a German e-commerce company. }\end{array}$ & (Cahya, 2018) \\
\hline 5 & Tokopedia & $\begin{array}{l}\text { Tokopedia was officially released to the public on August } 17 \text {, } \\
2009 \text { under the auspices of PT Tokopedia which was founded } \\
\text { by William Tanuwijaya and Leontinus Alpha Edison on } \\
\text { February } 6,2009 \text {. Tokopedia provides a free C } 2 \text { C platform for } \\
\text { sellers and buyers. }\end{array}$ & (Hendra, 2018) \\
\hline 6 & OLX Indonesia & $\begin{array}{l}\text { OLX is a classified ad site originating from New York, United } \\
\text { States. In Indonesia, they have acquired TokoBagus and } \\
\text { Berniaga in } 2014 \text { ago and are now led by Daniel Tumiwa as } \\
\text { CEO. }\end{array}$ & (Pratama, 2016) \\
\hline 7 & Bhinneka & $\begin{array}{l}\text { Bhinneka is one of the first e-commerce actors to appear in } \\
\text { Indonesia with electronic goods as its main product. This site } \\
\text { was founded in } 1993 \text {. }\end{array}$ & (Pratama, 2016) \\
\hline 8 & Blibli & $\begin{array}{l}\text { Blibli is the first product of PT Global Digital Niaga, a } \\
\text { subsidiary of Djarum in the digital field. Blibli.com brings the } \\
\text { concept of mall-style online shopping since } 2010 \text { and became } \\
\text { the first B2C e-commerce model in Indonesia. }\end{array}$ & (Cahya, 2018) \\
\hline 9 & Zalora & Zalora is one of the sites that provide clothing fashion needs. & (Cahya, 2018) \\
\hline
\end{tabular}




\begin{tabular}{|c|c|c|c|}
\hline & & $\begin{array}{l}\text { Zalora has a collection of more than } 500 \text { local, international, } \\
\text { and designer brands. The largest online fashion destination in } \\
\text { Southeast Asia was founded in early } 2012 \text { and is one of the } \\
\text { branches of Rocket Internet GmbH subsidiary. }\end{array}$ & \\
\hline 10 & Blanja.com & $\begin{array}{l}\text { Blanja.com is a joint venture between Telkom Indonesia and } \\
\text { eBay which is engaged in the e-commerce (C2C) market in } \\
\text { Indonesia since } 2012 \text {. }\end{array}$ & (Pamungkas, 2015) \\
\hline 11 & Kaskus & $\begin{array}{l}\text { Kaskus is actually an online forum created in 1999. But this } \\
\text { site later developed into one of the e-commerce platforms in } \\
\text { Indonesia. }\end{array}$ & (Pratama, 2016) \\
\hline
\end{tabular}

\section{Results}

Based on the results of the study, it was found that $56.3 \%$ of respondents were men, in the age range of Generation Z (1995 - 2010) of $88.8 \%$, had a monthly income level of $<$ IDR 2,000,000 of $49 \%$, and worked as students of $75.3 \%$. The majority of marketplaces used are Shopee (39.8\%), Tokopedia (33.3\%), and Bukalapak (11\%). The majority of respondents made purchases at marketplaces using smartphones by $83.8 \%$ with a frequency of purchases once in 2 months or less by $49.4 \%$.

Table 5.

Frequency Analysis of Demographic Characteristics

\begin{tabular}{|c|c|c|c|}
\hline Demographic Variables & Items & $\bar{n}$ & $\%$ \\
\hline \multirow[t]{2}{*}{ Sex } & Male & 303 & 56.3 \\
\hline & Female & 235 & 43.7 \\
\hline \multirow[t]{3}{*}{ Generation } & $X(1961-1980)$ & 28 & 5.2 \\
\hline & Y (1981 - 1994) & 32 & 6 \\
\hline & $Z(1995-2010)$ & 478 & 88.8 \\
\hline \multirow[t]{7}{*}{ Income per Month } & $<$ IDR 1.000 .000 & 132 & 24.5 \\
\hline & IDR 1.000 .000 - IDR 1.999 .999 & 132 & 24.5 \\
\hline & IDR 2.000.000 - IDR 2.999.999 & 112 & 20.8 \\
\hline & IDR 3.000 .000 - IDR 3.999 .999 & 58 & 10.8 \\
\hline & IDR 4.000.000 - IDR 4.999 .999 & 36 & 6.7 \\
\hline & IDR 5.000.000 - IDR 9.999 .999 & 36 & 6.7 \\
\hline & $>$ IDR 10.000 .000 & 32 & 6 \\
\hline \multirow[t]{8}{*}{ Profession } & Employee & 45 & 8.4 \\
\hline & College Student & 405 & 75.3 \\
\hline & Teacher/Lecturer & 2 & 0.4 \\
\hline & Entrepreneur & 20 & 3.7 \\
\hline & Freelancer & 7 & 1.3 \\
\hline & Housewife & 17 & 3.2 \\
\hline & Students (elementary, middle, high school) & 32 & 5.9 \\
\hline & Others & 10 & 1.8 \\
\hline \multirow{11}{*}{ Marketplaces } & Shopee & 214 & 39.8 \\
\hline & JD.id & 13 & 2.4 \\
\hline & Bukalapak & 59 & 11 \\
\hline & Lazada Indonesia & 22 & 4.1 \\
\hline & Tokopedia & 179 & 33.3 \\
\hline & OLX Indonesia & 9 & 1.7 \\
\hline & Bhinneka & 1 & 0.2 \\
\hline & Blibli & 4 & 0.7 \\
\hline & Zalora & 27 & 5 \\
\hline & Blanja.com & 3 & 0.6 \\
\hline & Kaskus & 7 & 1.2 \\
\hline \multirow{4}{*}{ Gadget for Purchase } & $\mathrm{PC}$ & 36 & 6.7 \\
\hline & Laptop & 45 & 8.4 \\
\hline & Smartphones & 451 & 83.8 \\
\hline & Tablet & 6 & 1.1 \\
\hline Frequency of Purchase & 2-3 times a week or more often & 21 & 3.9 \\
\hline
\end{tabular}




\begin{tabular}{lll}
\hline Once a week & 23 & 4.3 \\
Once in 2-3 weeks & 60 & 11.2 \\
Once a month & 168 & 31.2 \\
Once in 2 months or less & 266 & 49.4 \\
\hline
\end{tabular}

Source: Questionnaire's results

\subsection{The Importance of Digital Trust in e-Commerce}

Based on the results of the study, it is known that the most important factor in digital trust is credibility, which has an average number of 4.14 . Followed by security with 3.8 , transparency 3.79 , reliability 3.68 , and integrity 3.26. Maintaining credibility is one of the most important things in maintaining consumer digital trust in Bandung, Indonesia considering consumers will switch services where organizations do not fulfill their promises or commitments. In this case, the company must fulfill the promises or commitments offered in e-commerce, be it the quality of the goods, promos or bonuses obtained, conformity between promotional material and products obtained, and have a good reputation. The credibility of an online store can be assessed based on ratings and comments from previous buyers, both satisfied consumers and dissatisfied consumers.

Table 6.

\begin{tabular}{cc} 
Digital Trust Indicator & \\
\hline Digital Trust's Indicator & Mean \\
\hline Reliability & 3.68 \\
Credibility & 4.14 \\
Transparancy & 3.79 \\
Integrity & 3.26 \\
Security & 3.8 \\
Overall Digital Trust & 3.82 \\
\hline
\end{tabular}

Source: Results of data processing

\subsection{Digital Trust Affects the Brand Image of e-Commerce}

Based on the results of the study, digital trust can also influence the brand image of ecommerce. This can be seen from the results of data processing shown in the Table 7., so that simple linear regression equations can be obtained as follows:

$$
Y=1.056+0.797 X
$$

Table 7.

Coefficients Digital Trust and Brand Image

\begin{tabular}{llrrrrr}
\hline \multirow{2}{*}{ Model } & \multicolumn{2}{c}{ Unstandardized Coefficients } & \multicolumn{2}{c}{$\begin{array}{c}\text { Standardized } \\
\text { Coefficients }\end{array}$} & \multirow{2}{*}{ t } & \multirow{2}{*}{ Sig. } \\
\cline { 2 - 5 } & \multicolumn{1}{c}{ B } & Std. Error & Beta & & \\
\hline 1 & (Constant) & 1.056 & .136 & & 7.761 & .000 \\
& Digital Trust & .797 & .035 & .699 & 22.612 & .000 \\
R & $.699^{\mathrm{a}}$ & & & & \\
R Square & .488 & & & & \\
F Statistics & 511.306 & & & & \\
\hline
\end{tabular}

a. Dependent Variable: Brand Image

Source: SPSS results of data processing

In addition, the correlation value (R) obtained between digital trust and brand image is 0.699 which is classified as having a strong correlation, so there is a strong relationship between digital trust and brand image. The value of $\mathrm{R}$ square shows the contribution of digital trust to the brand image by $48.8 \%$. Likewise, $\mathrm{t}$ count $>\mathrm{t}$ table, which is $22,612>1,980$ with a significance value of $0,000<0.05$ at a $95 \%$ confidence level indicating that digital trust has 
positive and significant influence on brand image.

$\mathrm{H}_{1}$ : Digital trust has positive and significant influence on brand image accepted

\subsection{Digital Trust Affects Customer Loyalty}

Digital trust can also influence customer loyalty, both directly and mediated through a brand image.

Table 8.

Coefficients Digital Trust and Brand Image

\begin{tabular}{|c|c|c|c|c|c|c|}
\hline & \multirow[t]{2}{*}{ Model } & \multicolumn{2}{|c|}{ Unstandardized Coefficients } & $\begin{array}{l}\text { Standardized } \\
\text { Coefficients }\end{array}$ & \multirow[t]{2}{*}{$\mathrm{t}$} & \multirow[t]{2}{*}{ Sig. } \\
\hline & & $\mathrm{B}$ & Std. Error & Beta & & \\
\hline \multirow[t]{6}{*}{1} & (Constant) & 1.056 & .136 & & 7.761 & .000 \\
\hline & Digital Trust & .797 & .035 & .699 & 22.612 & .000 \\
\hline & $\mathrm{R}$ & 0.699 & & & & \\
\hline & R Square & 0.488 & & & & \\
\hline & Adj. R Square & 0.487 & & & & \\
\hline & F Statistics & 511.306 & & & & \\
\hline
\end{tabular}

a. Dependent Variable: Brand Image

Source: SPSS results of data processing

Based on the Table 8., simple digital trust regression equations can be formulated to the brand image as follows

$\mathrm{Y}=\beta_{1} \mathrm{X}+\mathrm{e}_{1}$

$\mathrm{Y}=0.699 \mathrm{X}$

Table 9.

Coefficients Digital Trust, Brand Image, and Customer Loyalty

\begin{tabular}{|c|c|c|c|c|c|c|}
\hline & \multirow{2}{*}{ Model } & \multicolumn{2}{|c|}{ Unstandardized Coefficients } & \multirow{2}{*}{$\begin{array}{c}\text { Standardized } \\
\text { Coefficients } \\
\text { Beta }\end{array}$} & \multirow[t]{2}{*}{$\mathrm{t}$} & \multirow{2}{*}{ Sig. } \\
\hline & & B & Std. Error & & & \\
\hline \multirow{7}{*}{1} & (Constant) & .511 & .137 & & 3.730 & .000 \\
\hline & Digital Trust & .560 & .047 & 494 & 11.885 & .000 \\
\hline & Brand Image & 287 & .041 & 289 & 6.947 & .000 \\
\hline & $\mathrm{R}$ & 0.726 & & & & \\
\hline & R Square & 0.527 & & & & \\
\hline & Adj. R Square & 0.525 & & & & \\
\hline & F Statistics & 297.847 & & & & \\
\hline
\end{tabular}

a. Dependent Variable: Customer Loyalty

Source: SPSS results of data processing

Based on the Table 9., we can conclude the equation as follows

$\mathrm{Z}=\beta_{2} \mathrm{X}+\beta_{3} \mathrm{Y}+\mathrm{e}_{2}$

$Z=0.494 X+0.289 Y+e_{2}$

The direct influence: the influence of digital trust $(\mathrm{X})$ on brand image $(\mathrm{Y})$ has a $\beta_{1}$ value $=$ 0.699 ; the influence of digital trust $(X)$ on customer loyalty $(Z)$ has a $\beta_{2}$ value $=0.494$; the influence of brand image $(\mathrm{Y})$ on customer loyalty $(\mathrm{Z})$ has a $\beta_{3}$ value $=0.289$

The indirect influence; the influence of digital trust $(\mathrm{X})$ on customer loyalty $(\mathrm{Z})$ with brand image $(Y)$ as the mediating variable: indirect influence $=\beta_{1} \times \beta_{3}=0.699 \times 0.289=0.202$ 
The total influence; the total influence of digital trust $(\mathrm{X})$ on customer loyalty through brand image is calculated as follows:

Total influence $\mathrm{t}=\beta_{2}+\left(\beta_{1} \times \beta_{3}\right)=0.494+(0.699 \times 0.289)=0.696$

Through equations (1) and (2), the final path diagram model can be formed. Before forming the final path diagram model, the standard error value should be calculated first.

The standard error value:

$\mathrm{e}_{1}=\sqrt{1-R 1^{2}}=\sqrt{1-0.487^{2}}=0.763$

$\mathrm{e}_{2}=\sqrt{1-R 2^{2}}=\sqrt{1-0.525^{2}}=0.724$

The total coefficient of determination is calculated as follows:

$\mathrm{R}^{2} \mathrm{~m}=1-\left(\mathrm{e}_{1}\right)^{2}\left(\mathrm{e}_{2}\right)^{2}$

$=1-(0.763)^{2}(0.724)^{2}$

$=1-(0.582)(0.524)$

$=1-0.305=0.695$

The total determination value is 0.695 which can be interpreted as 69.5 percent of customer loyalty is influenced by the variation in digital trust and brand image, while the remaining 30.5 percent is explained by other factors not included in the model.

Table 10.

t count and t table Result

\begin{tabular}{cccc}
\hline Influence of Variables & t count & t table & Results \\
\hline $\mathrm{X} \rightarrow \mathrm{Z}$ & 11.885 & 0.000 & $\mathrm{H}_{2}$ accepted \\
$\mathrm{Y} \rightarrow \mathrm{Z}$ & 6.947 & 0.000 & $\mathrm{H}_{3}$ accepted \\
\hline
\end{tabular}

Source: SPSS results of data processing

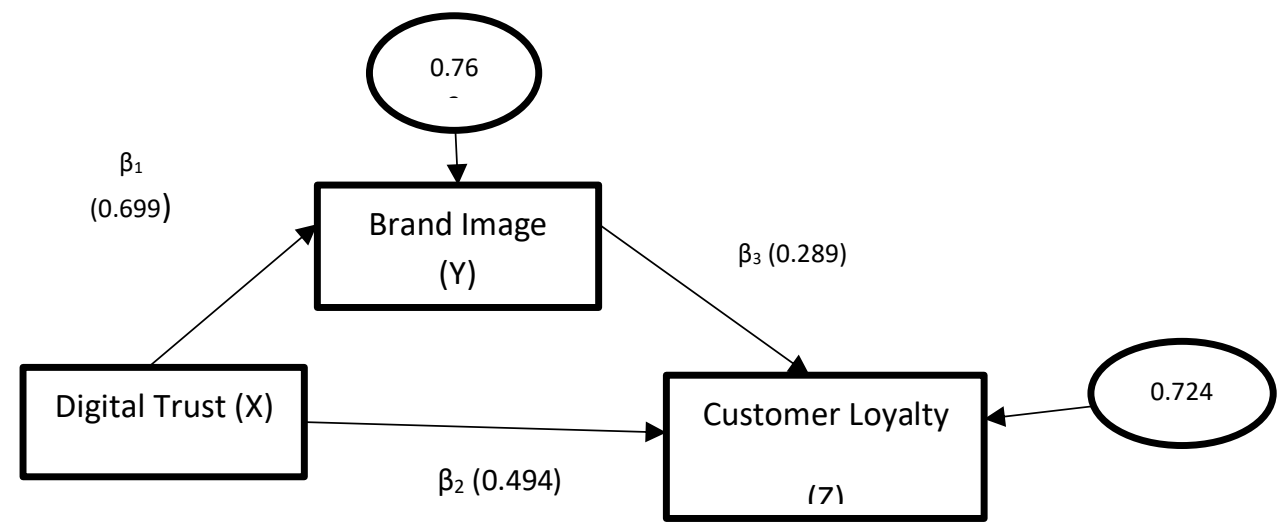

Figure 4. Path Analysis Results. Source: SPSS results of data processing

In the Figure 3., it can be seen that digital trust variable has the largest influence on brand image variable with a loading factor value of 0.699. Digital trust also has an influence on customer loyalty variable with a loading factor value of 0.494 and there is also an indirect influence on customer loyalty through brand image variable with a loading factor value of 0.289 .

Table 11.

Direct, Indirect, and Total Influence

\begin{tabular}{cccc}
\hline Influence of Variables & Direct Influence & $\begin{array}{c}\text { Indirect Influence } \\
\text { through Brand Image }\end{array}$ & Total Influence \\
\hline$X \rightarrow$ Y & 0.699 & - & 0.699 \\
$X \rightarrow Z$ & 0.494 & 0.202 & 0.696 \\
Y $\rightarrow$ Z & 0.289 & - & 0.289 \\
\hline
\end{tabular}

Source: SPSS results of data processing 
On Table 11. the direct influence of $\mathrm{X}$ on $\mathrm{Y}$ is 0.699 . There are no indirect influence, thus the total influence is 0.699 . The direct influence of $\mathrm{X}$ on $\mathrm{Z}$ is 0.494 . The indirect influence of $\mathrm{X}$ on $Z$ through $Y$ is attained from the calculation of $0.699 \times 0.289=0.202$. Thus, the total influence of $\mathrm{X}$ on $\mathrm{Z}$ through $\mathrm{Y}$ is $0.494+0.202=0.696$. This means that digital trust has an indirect influence on customer loyalty mediated by brand image.

The Sobel test is an analysis tool to examine the significance of the indirect influence between the independent variable and the dependent variable which is mediated by the mediator variable. If the $Z$ value is greater than 1.96 (with a confidence level of 95 percent), the mediator variable is deemed to have a significant effect (Ghozali, 2013).

Table 12.

Sobel Test Result

\begin{tabular}{cc}
\hline Z Value & Sig \\
\hline 6.690997 & 0.000 \\
\hline
\end{tabular}

Source: SPSS results of data processing

Based on the Table 12., the $\mathrm{Z}$ value is shown to be $6.690997>1.9$ with a significance level of $0.000<0.05$ which means that the brand image variable significantly mediates the influence of digital trust on customer loyalty. These results indicate that digital trust is mediated by brand image to provide a significant influence on customer loyalty. Digital trust is a crucial factor in forming a brand image which ultimately has implications for customer loyalty.

$\mathrm{H}_{4}$ : Brand image is able to significantly mediate the influence of digital trust on customer loyalty accepted

\section{Conclusion and Recommendation}

The results of this study can be used for answering (1) the importance of digital trust in eCommerce; (2) how digital trust affects the brand image of e-Commerce; (3) how digital trust affects customer loyalty.

\subsection{The Importance of Digital Trust in e-Commerce}

Digital trust plays an important role in e-commerce business, especially in terms of credibility, security, and transparency. The credibility of an e-commerce can be determined by ratings and comments from previous buyers, both satisfied consumers and dissatisfied consumers. In terms of security, consumers want their personal data to be safe and not used by irresponsible parties. In terms of transparency, consumers want e-commerce to be open in utilizing the data provided for certain purposes.

Therefore, e-commerce can develop digital consumer trust by ensuring that online stores, both those managed by e-commerce and individuals by sellers in maintaining the quality of products sold, and ensuring that all promotional materials received by consumers are real and can be utilized by consumer. Keeping digital trust consumers is not easy with the many social media channels that consumers can use to get a lot of information about products, so e-commerce must wisely maintain digital consumer trust, especially in managing service quality control.

\subsection{Digital Trust Affects the Brand Image of e-Commerce}

Digital trust also has a significant effect on brand image from e-commerce. In other words, consumer trust will determine the brand image of e-commerce in question. Consumers can labeling or stamping on e-commerce that often neglects consumer demand. Consumers can also assess the brand image of e-commerce only from one or a portion of online stores selling in e-commerce, so e-commerce needs to standardize excellent service for every online store that sells so that digital consumer trust has implications for the whole brand image from ecommerce. 


\subsection{Digital Trust Affects Customer Loyalty}

Digital trust has a direct influence as well as mediation through the brand image of customer loyalty. When consumers feel their digital trust is fulfilled in an e-commerce, then they will positively view the e-commerce brand image and tend to have high loyalty to the e-commerce brand. Maintaining loyal customers will certainly be a challenge for e-commerce, so loyalty programs, such as giving cashback shopping with credit that can only be used in e-commerce, birthday discounts, spending points, and VIP bookings can be given to loyal consumers, so that it has a positive impact on e-commerce businesses.

The limitation of this study lies in the scope of the research in Bandung, Indonesia, so that it cannot represent the overall online shopping behavior of the people in Indonesia. The future research that can be done is measuring consumer sensitivity to prices in testing whether digital trust is still a significant factor in determining consumer loyalty. In addition, research can be carried out on a wider scale, for example West Java or Indonesia.

\section{References}

Cahya, P. (2018, June 28). 10 E-Commerce Terbaik yang Menggeser Eksistensi Toko Offline. Diambil kembali dari IDN Times: https://www.idntimes.com/business/economy/putrianacahya/10-e-commerce-terbaik-yang-menggeser-eksistensi-toko-offline/full

CareerRide.com. (2019, May 6). E/M-Commerce for Computer Science and MCA students. Diambil kembali dari CareerRide.com: https://www.careerride.com/page/em-commercefor-computer-science-and-mca-students-668.aspx

Chakravorti, B., Bhalla, A., \& Chaturvedi, R. S. (2018, February 19). The 4 Dimensions of Digital Trust, Charted Across 42 Countries. Diambil kembali dari Harvard Business Review: $\quad$ https://hbr.org/2018/02/the-4-dimensions-of-digital-trust-charted-across-42countries

Chambers, S. (2018, February 21). The Importance of Customer Loyalty. Diambil kembali dari Nicereply: https://www.nicereply.com/blog/the-importance-of-customer-loyalty/

Daniel, W. (2019, March 11). Wow! Transaksi e-Commerce RI 2018 Capai Rp 77 T, Lompat 151\%. Diambil kembali dari CNBC Indonesia: https://www.cnbcindonesia.com/fintech/20190311101823-37-59800/wow-transaksi-ecommerce-ri-2018-capai-rp-77-t-lompat-151

Das, D. (2018, March 15). Types of E-Commerce Business Models with Diagram \& Examples. Diambil kembali dari csetutor.com: https://www.csetutor.com/what-is-e-commerce-typesof-e-commerce/

Deheshti, M., Firouzjah, J. A., \& Alimohammadi, H. (2016). The Relationship between Brand Image and Brand Trust in Sporting Goods Consumers. Annals of Applied Sport Science, vol. 4, no. 3, 27-34.

Ghozali, I. (2013). Aplikasi Analisis Multivariate dengan Program IBM SPSS 21. Semarang: Badan Penerbit Universitas Diponegoro.

Hajli, N., Mohana Shanmugam, Savvas Papagiannidis, Debra Zahay, \& Marie-Odile Richard. (2017). Branding co-creation with members of online brand communities. Journal of Business Research 70, 136-144.

Hartomo, G. (2019, January 25). 24\% Uang Konsumen Hilang Ditipu Belanja Online. Diambil kembali dari Okezone.com: https://economy.okezone.com/read/2019/01/25/320/2009323/24-uang-konsumen-hilangditipu-belanja-online 
Hendra, D. (2018, March 8). Jalan Panjang Tokopedia Menjadi Unicorn Indonesia. Diambil kembali dari SWA: https://swa.co.id/swa/profile/jalan-panjang-tokopedia-menjadiunicorn-indonesia

Kement, Ü., \& Çavuşoğlu, S. (2017). Hafızaya Yönelik Müşteri Deneyimlerinin Müşteri Sadakatine Etkisi: Yeşil Oteller Örneği. Uluslararası Sosyal ve Eğitim Bilimleri Dergisi, Vol. 4 No. 8, 172-194.

Kim, M.-K., Myeong-Cheol Park, Jong-Hyun Park, Jimin Kim, \& Eunhye Kim. (2018). The role of multidimensional switching barriers on the cognitive and affective satisfactionloyalty link in mobile communication services: Coupling in moderating effects. Computers in Human Behavior 87, 212-223.

Kotler, P., \& Keller, K. L. (2013). Manajemen Pemasaran. Jakarta: Penerbit Erlangga.

KPMG. (2015). Digital Trust. UK: KPMG.

Oxford University Press. (2019). Trust. Diambil kembali dari Oxford University Press: https://en.oxforddictionaries.com/definition/trust

Pamungkas, G. (2015, September 4). E-commerce blanja.com. Diambil kembali dari Galih Pamungkas: http://umum.galihpamungkas.com/2015/09/04/e-commerce-blanja-com/

Pratama, A. H. (2016, March 16). [Update] Kumpulan Toko Online Populer di Indonesia. Diambil kembali dari Tech In Asia: https://id.techinasia.com/toko-online-populer-diindonesia

Pujadi, B. (2010). Studi Tentang Pengaruh Citra Merek Terhadap Minat Beli Melaui Sikap Terhadap Merek. Semarang: Program Magister Manajemen Universitas Diponegoro.

Punch, K. F. (2013). Introduction to social research: Quantitative and qualitative approaches. Sage.

Semadi, I. Y., \& Ariyanti, M. (2018). The Influence Of Brand Experience, Brand Image, and Brand Trust on Brand Loyalty Of ABC-CASH. Asian Journal of Management Sciences \& Education Vol. 7(3), 12-23.

Tutorials Point. (2019, May 6). E-Commerce - Business Models. Diambil kembali dari Tutorials Point: https://www.tutorialspoint.com/e_commerce/e_commerce_business_models.htm

Wahyuningsih, R. (2018, July 13). 5 Alasan Kenapa Banyak Orang Beralih ke Belanja Online. Diambil kembali dari Cermati.com: https://www.cermati.com/artikel/5-alasan-kenapabanyak-orang-beralih-ke-belanja-online

Wijaya, H. R., \& Astuti, S. R. (2018). The Effect of Trust and Brand Image to Repurchase Intention in Online Shopping. International Conference on Economics, Business and Economic Education 2018 (hal. 915-928). KnE Social Sciences.

Winarso, S. (2012). Pengaruh Nilai Pelanggan dan Citra Merek serta Hambatan Berpindah terhadap Kepuasan dan Loyalitas Pelanggan Maskapai Penerbangan Lion Air di Bandara Internasional Sepinggan Balikpapan. Surabaya: Program Pascasarjana Universitas Airlangga. 